\title{
Length Attainment and Stunting Prevalence of Children aged 0-24 Months Living in the Area of Clay Brick Kilns in Pagar Merbau Sub District, Indonesia
}

\author{
Haripin Togap Sinaga ${ }^{1}$ D , Nurman Achmad ${ }^{2 *}$ (D), Mincu Manalu ${ }^{1}$, Susanti Perangin-Angin ${ }^{3}$, Lusyana Gloria Doloksaribu ${ }^{1}$ \\ ${ }^{1}$ Department of Nutrition, Politeknik Kesehatan Medan, Medan, Indonesia; ${ }^{2}$ Department of Anthropology, Universitas Sumatera \\ Utara, Medan, Indonesia; ${ }^{3}$ Department of Environmental Health, Politeknik Kesehatan Medan, Medan, Indonesia
}

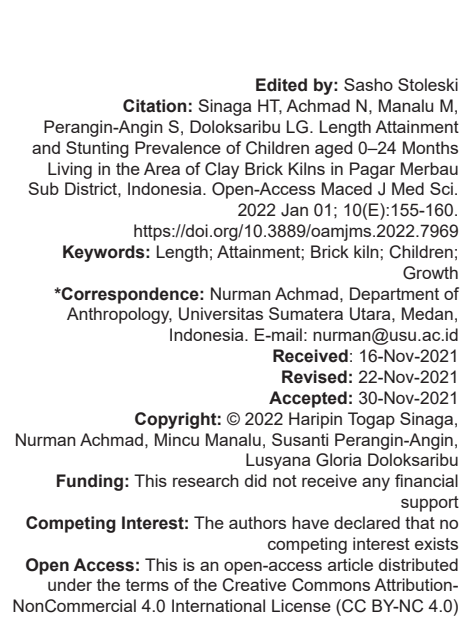

Introduction

The association of air pollution with children's health and children's growth has been proved. Recently, several studies found that household air pollution, indoor solid fuel, and exposure to kitchen smoke have a negative impact on children's health [1], [2] including anthropometric measurements [3], [4]. A study conducted by Bobak et al. who revealed that the effect of air pollution on children's height started at age 2 and become clear at the age of 7 [4].

The effect of air pollution contributed to 3-9\% of stunted prevalence [5], [6]. Bhagowalia found that building a kitchen in the living room increases the odds of stunting [7]. Mishra and Retherford found the impact of solid fuel use on the predominance of anemia and stunting among Indian children [8].

The negative health consequences of being exposed to household air pollution also contribute to acute respiratory problems [9] and cigarette smoke has a negative effect on fetal head size [10], outdoor air pollution have relation to children growth [4], [11] and to cognitive and physical health [1].

The clay bricks industry is considered the cause of household air pollution. The emission of harm full gasses produced by the kilns treats children who reside surrounding kilns. In production activities, most kilns use cheaper form fuel such as palm crop wastes, woods, and industrial oil which aggravates the mixture of containments such as metals, compounds volatile organics, and persistent organic compounds [1].

Indonesia is a developing country that has a large number of villages and populations. Based on a survey in 2015, the population in Indonesia is 255.2 million of which $51 \%$ of people live in villages [12]. Among 13 types of factory works, working in a clay brick kiln is one of the most sources of family income for villagers [13]. Therefore, clay brick kiln is easily found in villages across Indonesia [14]. However, it will be a challenge for the Indonesian government in reducing the prevalence of stunting from $30.7 \%$ [15] to $14.0 \%$ in 2024 [16]. Furthermore, the number of 
newborn babies with birth lengths lowers than $48 \mathrm{~cm}$ increases from $20.2 \%$ to $22.7 \%$ [17].

In the location of this study, more than 200 clay brick kilns and more than 50 trucks pass in and out in two villages. Therefore, families and children who live in the villages are used to inhaling smoke and dust that harm full gasses. The researchers assumed that these heavy particles might have brought a negative effect on maternal health and the growth of children.

Height growth attainment is a desirable approach to measure growth according to agedependent changes [18]. In addition, the WHO anthropometric standards provide standard deviation (SD) and growth curve in the growth chart. The growth chart provides seven curves in which the curve shows how children should grow and SD. Children whose height is below -2 to -3 SD from the median WHO child growth standard are categorized as moderate stunting. Higher minus two to positive three (>-2SD to +3SD) categorized as normal. It means that the position of OSD is between these categories [19], [20]. These categories are presented in the growth curve chart of length-for-age. The growth curve is now widely accepted as a guideline to monitor children's health status. It is expected that the growth curve of children is above the median [21].

The advantages for the community nutrition program, it could be a tool to present what is happening in children's growth at present [22] and to predict the changes leading to adiposity and prevent mortality [23]. In this study, we define length attainment as how close length growth attains the median growth standard. Therefore, the present study aims to assess the difference in length attainment and stunting prevalence of children living in the areas of clay brick kiln and non-clay brick kilns.

\section{Methods}

\section{Study design, location, and participants}

The study was a cross-sectional study conducted from February to December 2020. The location of the study was in Pagar Merbau Subdistrict,

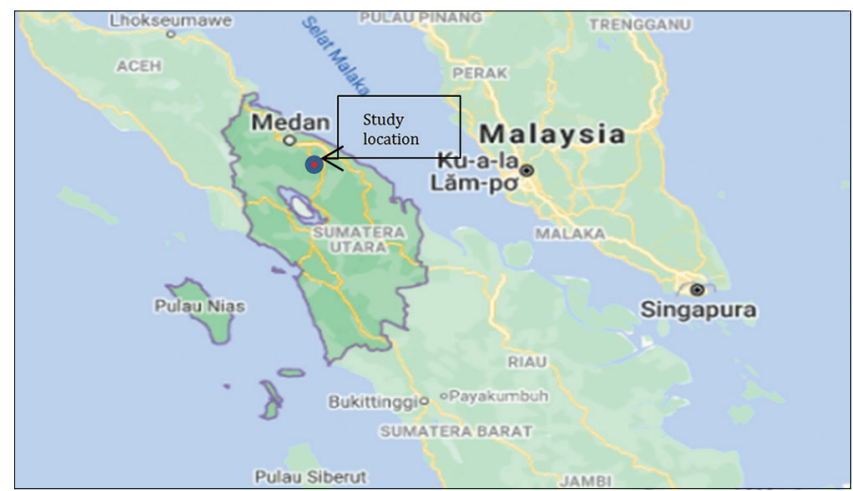

Figure 1: Map of location of the study point in North Sumatera Province
Deli Serdang District, North Sumatera Indonesia. It is located in the Western part of Indonesia, belongs to North Sumatera Province (Figure 1). It is about 50 km from Medan, the capital city of North Sumatra. Pagar Merbau served an approximately $62.89 \mathrm{~km}^{2}$ area with 16 villages. The population is around 43,000 people living in 16 villages. Four among 16 villages were selected purposively to be the location of study. Tanjung Mulia and Purwodadi villages were determined as the study group. These two villages are in neighbor. In these two villages, there are more than 200 clay brick kilns that had been established since the 1970s. The position kilns are located within the community settlement. Every day starting at 04.00 PM, more than 50 trucks pass in and out the villages to take the materials make the air quality is bad.

More than $60 \%$ of total families earn living by working as laborers in the kilns. Materials used to burn the bricks are woods and palm fruit nests. The burning process takes at least 3-5 days non-stop after the clay bricks are dried for $10-5$ days (Figure 2 ).

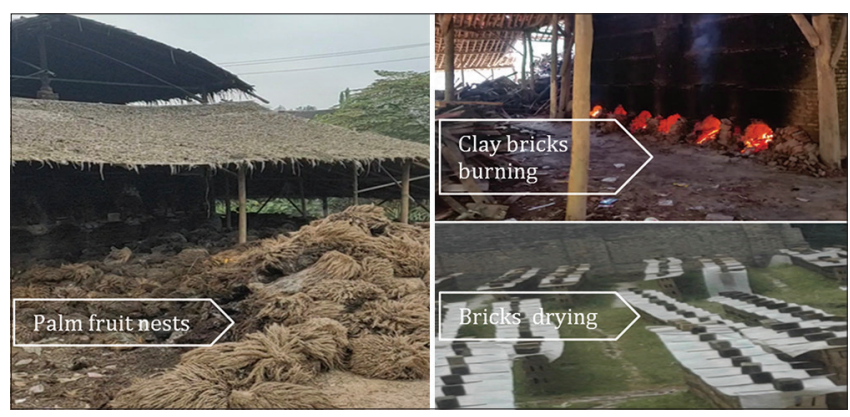

Figure 2: Clay brick kiln at location of study

Two other villages, Pasar Miring and Perbarakan that have no clay brick kilns, were determined as the control study. To identify the group of study, we used CBK for villages with clay brick kilns and non-CBK for villages that have no clay brick kilns. The distance between CBK villages and non-CBK is five to six kilometers.

This sub-district has one public health center and community health post in each village managed by the community midwife. Growth monitoring, immunization, distribution of Vitamin A supplementation, and food supplementation are part of the community nutrition program for children and mothers.

Participants of the study were mothers who have children aged 0-24 months. Households were selected based on the purpose of the study. First, total households who have children line in the villages were determined as the population of the study. Then, families who have children under 2 years old were determined as participants. Respondents were selected purposively with such criteria; children are not twin babies, born normal condition, living in radius $2 \mathrm{~km}$ from clay brick kiln, and have been living in the villages more than 5 years and mother is willing to be the respondent of study. The total number of participants was 192 families 
who have children aged 0-24 years old. If two babies were found in the family, only one was recruited as the sample. All participants were provided written informed consent for their participation in the survey.

\section{Data collection}

Types of data collected were family characteristics including socioeconomic, education, occupation, the number of children, birth weight and length, current weight and length, age, and sex. Length of children was measured by trained enumerators using a regularly calibrated length board. Two times measurements were taken for each child. During data collection, the researchers observed how enumerators measured children's length, interviewed mothers/ guardians and recorded the data. The results of length should have comas in millimeters.

\section{Data processing}

The height/length-for-age $Z$ scores (HAZ) of children were collected based on sex. Median standard WHO 2006 of length-for-age is used as the reference to assess the length attainment. For example, the median standard of length for age at age 3 months is $61.4 \mathrm{~cm}$, if the current length is $60.4 \mathrm{~cm}$ means that the length attainment is $-1.0 \mathrm{~cm}$.

To assess the difference of height of children between the non-CBK and CBK group, data of the same age was subtracted. For example, the length of children in non-CBK at age 21 months is $84.2 \mathrm{~cm}$ and in CBK 82.4, which means that the difference is $1.8 \mathrm{~cm}$ or children in CBK are shorter $1.8 \mathrm{~cm}$ than children in non-CBK. To determine the prevalence of stunting, the number of children who have length-for-age below minus 2SD was calculated. All data were processed using SPSS version 20.0.

\section{Presenting length attainment}

Length attainment was presented in the growth curve using bubble growth created by Sinaga et al. [24] and in the table. The bubble chart provides seven growth curves according to SD; $-3 S D,-2 S D, 0 S D,+1 S D,+2 S D$, and $+3 S D$. The curves in this growth chart were taken from recent anthropometric international references released by the WHO 2006 [20], [25]. Three months interval of length was plotted in the chart and presented in the table. The difference between median standard with current length was determined as length attainment. Since data on age and gender were available in the survey, therefore, the presence of the growth chart was presented for boys and girls.

\section{Statistical analysis}

Statistical analysis was done to assess the comparison of socioeconomic characteristics and children characteristics between two groups of study. To determine whether the groups were comparable, pair t-tests were applied. Meanwhile, to test the significant difference in prevalence of stunting between the two groups, Chi-square test was applied.

\section{Results}

\section{Characteristics of families and children}

The researchers determined 10 characteristics of households and children for both areas of study. The indices were father and mothers' education, occupation, income, BMI, sex and age of children, birth weight, and birth length. These variables were compared using the pair t-test. Heterogeneity was found in most indices in two groups of study. All indices were comparable ( $p>0.05)$.

Table 1 shows the comparison of length attainment and the length difference of boys between children in the study group and control group. Table 1 presents that the length average of children aged 0-6 months was over the median WHO standard. During this period, the length attainment of children in two groups of study reached higher than the median standard. However, entering the age 9 months until age 24 months, in the study group and aged 15-24 months in the control group, the length attainment tended to be minus. At aged 18-24 months, the length attainment of boys who lived in the areas of clay brick kilns areas lagged $1.1-1.9 \mathrm{~cm}$ and shorter $0.8-1.9 \mathrm{~cm}$ compared to boys who live in the least polluted areas.

Table 1: Length attainment of children in two groups of study, boys

\begin{tabular}{|c|c|c|c|c|c|c|}
\hline \multirow[t]{2}{*}{$\begin{array}{l}\text { Three months } \\
\text { interval of age }\end{array}$} & \multicolumn{2}{|c|}{$\begin{array}{l}\text { Average of length } \\
(\mathrm{cm} \pm \mathrm{SD})\end{array}$} & \multirow[t]{2}{*}{$\begin{array}{l}\text { Median WHO standard } \\
\text { (length for age) }\end{array}$} & \multicolumn{2}{|c|}{ Length attainment ${ }^{*}$} & \multirow[t]{2}{*}{$\begin{array}{l}\text { Difference length non- } \\
\text { CBK to CBK }(\mathrm{cm})\end{array}$} \\
\hline & $\begin{array}{l}\text { Study group } \\
\text { (CBK) n=101 }\end{array}$ & $\begin{array}{l}\text { Control group } \\
\text { (non-CBK) } n=91\end{array}$ & & $\begin{array}{l}\text { Study group } \\
\text { (CBK) }\end{array}$ & $\begin{array}{l}\text { Control group } \\
\text { (non-CBK) }\end{array}$ & \\
\hline 0 & $50.1 \pm 0.7$ & $50.1 \pm 0.6$ & 49.5 & +1.4 & +1.4 & 0.0 \\
\hline 3 & $61.8 \pm 0.8$ & $62.2 \pm 0.6$ & 61.4 & +0.4 & +0.8 & 0.4 \\
\hline 6 & $67.8 \pm 0.9$ & $68.0 \pm 0.8$ & 67.6 & +0.2 & +0.4 & 0.2 \\
\hline 9 & $71.8 \pm 0.9$ & $72.0 \pm 0.9$ & 72.0 & -0.2 & 0.0 & 0.2 \\
\hline 12 & $75.5 \pm 1.6$ & $76.3 \pm 1.3$ & 75.7 & -0.2 & +0.6 & 0.8 \\
\hline 15 & $78.5 \pm 1.5$ & $79.0 \pm 1.4$ & 79.1 & -0.6 & -0.1 & 0.5 \\
\hline 18 & $81.2 \pm 1.4$ & $82.0 \pm 1.6$ & 82.3 & -1.1 & -0.3 & 0.8 \\
\hline 21 & $83.2 \pm 1.6$ & $84.2 \pm 1.8$ & 85.1 & -1.9 & -0.9 & 1.0 \\
\hline 24 & $86.0 \pm 1.8$ & $87.1 \pm 1.7$ & 87.8 & -1.8 & -0.7 & 1.9 \\
\hline
\end{tabular}


Figure 3 depicts the growth curve of children (boys) from age 0 until age 24 months with 3 months interval of plotting. From the age of 0 months until 11 months, the growth curve of children in the two groups study was in line with the median curve (OSD). The growth curve of children who lived in CBK was a bit lower than the median at the age of 3-9 months. While the growth curve of children who lived in non-CBK, at aged 0 until 10 months, was consistently following the median curve, but then at aged 10-13 months, the curve tends to increase. At the age of 21-24 months, the length of children in both group tended to go down. Length attainment of children in CBK tended to go down to reach $-1 \mathrm{SD}$ line.

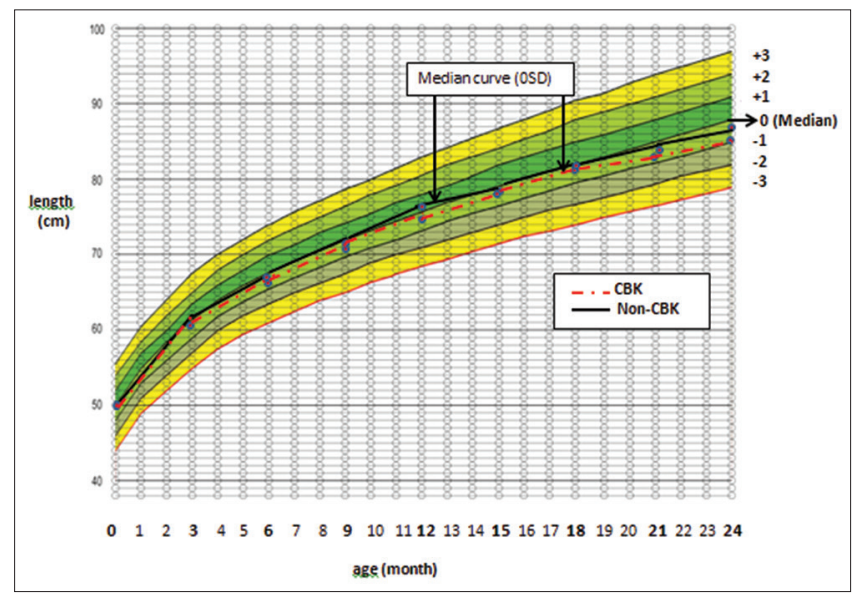

Figure 3: Length growth curve of children in two groups of study for boys

Table 2 shows the length attainment of girls children in two groups of study. At the aged 0-9 months, the length attainment was higher than median. It can be seen from the table that at the age of 3-9 months, the length of children in both groups were higher than the median standard ( 0.8 to $2.3 \mathrm{~cm}$ and 1.0 to $2.4 \mathrm{~cm}$ ) in $\mathrm{CBK}$ and non-CBK respectively. However, at the age of 18 months to 24 months, the length attainment of children in two groups tended to be slow and less than median $(-1.5$ to $-2.0 \mathrm{~cm}$ and -0.3 to $-0.7 \mathrm{~cm})$ in $\mathrm{CBK}$ and non-CBK respectively.

At age 18-24 months, the length attainment of girls lived in the areas of clay brick kilns areas lagged $1.5-2.0 \mathrm{~cm}$ and shorter $0.8-1.2 \mathrm{~cm}$ compared to girls who lived in non-CBK.

Figure 4 demonstrates the growth curve of children for girls from aged 0 until age 24 months by 3 months interval of plotting. From the age of 0 months until 3 months, the growth lines of children in the two groups were climbing above the median growth to reach +1SD. Then from ages 3-9 months, the growth line either in the study group or control study decreased to reach median (0SD). From 9 until 24 months, the growth line of children in CBK was consistently lower than the growth line of children in non-CBK. At the age of 24 months, the growth curve of children in non-CBK areas was at 0 SD and CBK was closer to -1 SD.
Table 3 shows that the prevalence of stunting of children who lived in clay brick kilns areas was a bit higher than in non-CBK, $19.8 \%$ and $18.6 \%$ respectively. The rests of children $(80.2 \%$ in $\mathrm{CBK}$ and $81.6 \%$ in nonCBK) were categorized as normal ( $-2 S D$ to $+3 S D$ length-for-age). However, less than half of those normal children reached the median WHO standard (>0SD). The Chi-square test proved that there was no significant difference in nutritional status between CBK children and non-CBK children $(p>0.05)$

\section{Discussion}

Only a few studies focused on the link between outdoor pollution and to height attainment of children. In our study, we intend to assess the negative effect of smoke that produces heavy particles on the length of growth of under 2 years children.

This study found that only at certain ages particularly at aged 0-12 months children can reach the median WHO standard of height-for-age. The average birth length of children in two areas of study was normal $(>49 \mathrm{~cm})$. It meant that even though mothers have contaminated with heavy particles from outdoor pollution and did not bring a negative impact to babies' growth. However, in the aged 12-24 months, the negative effect of outdoor pollution might have existed. As shown in Tables 1 and 2, at the aged 18-24 months, the length attainment of boys who lived in the areas of clay brick kilns areas lagged $1.1-1.9 \mathrm{~cm}$ and shorter $0.8-1.9 \mathrm{~cm}$ compared to boys who live in the least polluted areas.

These findings are quite similar to a study conducted by Bobak who found that the negative effect of outdoor pollution on height started at age 2 years and become more significant at age 7 years. Children aged 7 who lived in clay brick kiln areas were shorter $2 \mathrm{~cm}$ than children in clean areas [4]. Another finding on the relationship between air pollution to schoolchildren reported by Nikolić et al. They found that before the age of 9 , the effect of black smoke, nitrogen dioxide, sulfur dioxide, and lead sediment matters has brought effect to weight and height attainment of children school [26].

The effect of brick kilns emissions on growth depends on the distance of children to the source of the smoke. The study by Nasir et al. found that from radius 2-3 km, residing will be more deficit to height [12]. While in our study, more families lived closer to kilns, which were around the radius of $500 \mathrm{~m}-1 \mathrm{~km}$. We assumed that when children aged $>12$ months were more frequent breathing and inhale more heavy particles from nitrogen dioxide and carbon monoxide. The confirmation proved by a study in Arabian schoolboy children proved that low height measurements were 
Table 2: Length attainment of children in two groups of study, girls

\begin{tabular}{|c|c|c|c|c|c|c|}
\hline \multirow{2}{*}{$\begin{array}{l}\text { Three months } \\
\text { interval of age }\end{array}$} & \multicolumn{2}{|c|}{ Average of length $(\mathrm{cm} \pm \mathrm{SD})$} & \multirow{2}{*}{$\begin{array}{l}\text { Median WHO } \\
\text { standard }\end{array}$} & \multicolumn{2}{|c|}{ Length attainment ${ }^{*}$} & \multirow{2}{*}{$\begin{array}{l}\text { Difference of length } \\
\text { non-CBK to CBK }(\mathrm{cm})\end{array}$} \\
\hline & $\begin{array}{l}\text { Study group } \\
(\mathrm{CBK}) \mathrm{n}=101\end{array}$ & $\begin{array}{l}\text { Control group } \\
(\text { non- } \mathrm{CBK}) \mathrm{n}=91\end{array}$ & & $\begin{array}{l}\text { Study group } \\
\text { (CBK) }\end{array}$ & $\begin{array}{l}\text { Control group } \\
\text { (non- CBK) }\end{array}$ & \\
\hline 0 & $49.6 \pm 0.6$ & $49.8 \pm 0.6$ & 49.1 & +0.5 & +0.7 & 0.2 \\
\hline 3 & $62.1 \pm 0.6$ & $62.2 \pm 0.7$ & 59.8 & +2.3 & +2.4 & 0.1 \\
\hline 6 & $66.5 \pm 0.5$ & $66.9 \pm 0.8$ & 65.7 & +0.8 & +1.2 & 0.4 \\
\hline 9 & $69.3 \pm 1.0$ & $71.1 \pm 1.1$ & 70.1 & +0.8 & +1.0 & 0.8 \\
\hline 12 & $74.0 \pm 0.9$ & $74.3 \pm 0.9$ & 74.0 & -0.3 & +0.3 & 0.3 \\
\hline 15 & $77.4 \pm 1.4$ & $77.8 \pm 1.4$ & 77.5 & -0.1 & +0.1 & 0.4 \\
\hline 18 & $79.2 \pm 1.6$ & $80.0 \pm 1.5$ & 80.7 & -1.5 & -0.7 & 0.8 \\
\hline 21 & $81.7 \pm 1.5$ & $82.9 \pm 1.6$ & 83.7 & -2.0 & -0.8 & 1.2 \\
\hline 24 & $84.5 \pm 1.7$ & $86.1 \pm 1.8$ & 86.4 & -1.9 & -0.3 & 1.1 \\
\hline
\end{tabular}

${ }^{*}$ The difference between median WHO standard and average of length. SD: Standard deviation.

associated with exposure to $>0.35 \mathrm{ppm}$ of carbon monoxide and nitrogen dioxide [3].

Table 3: Length status based on distribution of SD length-for-age

\begin{tabular}{|c|c|c|c|c|c|}
\hline \multirow[t]{2}{*}{ Category length/age (SD) } & \multicolumn{2}{|c|}{$\begin{array}{l}\text { CBK } \\
\mathrm{n}=101\end{array}$} & \multicolumn{2}{|c|}{$\begin{array}{l}\text { Non-CBK } \\
n=91\end{array}$} & \multirow[t]{2}{*}{$p$-value } \\
\hline & $\mathrm{n}$ & $\%$ & $\mathrm{n}$ & $\%$ & \\
\hline $\begin{array}{l}\text { Stunting } \\
(-3 \text { SD to }<-2 S D)\end{array}$ & 20 & 19.8 & 17 & 18.6 & 0.45 \\
\hline $\begin{array}{l}\text { Normal } \\
(-2 \mathrm{SD} \text { to<0SD) }\end{array}$ & 50 & 49.5 & 46 & 50.5 & \\
\hline $\begin{array}{l}\text { Normal } \\
(>0 \text { SD to }<+3 \text { SD) }\end{array}$ & 31 & 30.7 & 38 & 41.5 & \\
\hline
\end{tabular}

Two growth charts presented in this study depicted that the growth curves of children in both locations of studies could not reach +1SD. Moreover, in entering age 18-24 months, the growth lines tend to -1SD. We also found that the prevalence of stunting was 18-20\%. These findings might have proved that the height velocity of children at the age of 18 to 24 months was very slow and they will be prone to be stunted after these age. This study found that around $19.0 \%$ of children were stunted. Even though there was $1.2 \%$ difference of prevalence of stunting between two location of study (19.8 vs $18.6 \%$ ), however it was not significantly difference. These findings prove that at the first 1000 days of life, one-fifth of children have been suffering from stunting and closer to the WHO borderline of $20 \%$ as a community health problem [27].

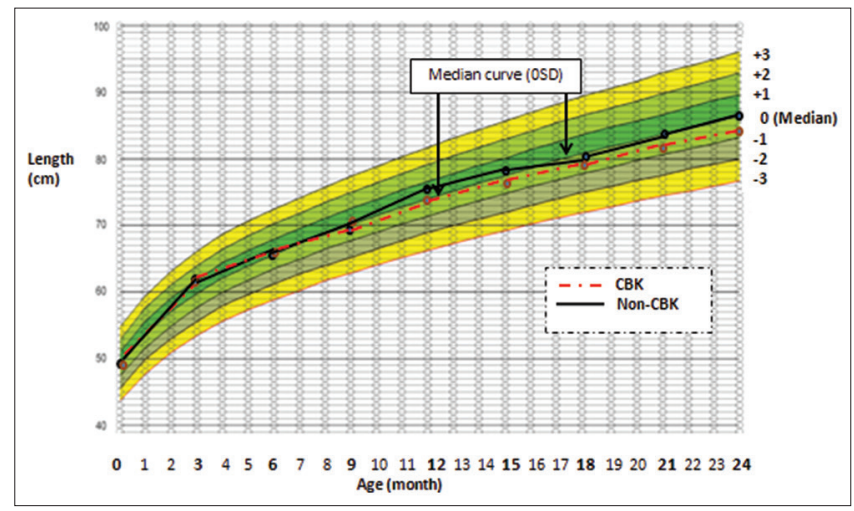

Figure 4: Length growth curve of children in two groups of study for girls

One important point that needs to discuss is how to recover stunted children to prevent them from severely stunted and low cognitive function. The perfect time to input nutrition to recover stunting children is at a young age, 12-36 months, not more than 5 years [28].

Our study confirms with several studies that have proved that there was an association of indoor air pollution and outdoor air pollution and stunting [5], [6], [7], [8] and other and anthropometric measurement and physical health [1], [4].

Therefore, the Indonesian government should take action and manage the establishment of clay brick kilns in villages and promote cleaner walling materials. Otherwise, the target of $14 \%$ prevalence stunting in 2024 will be difficult to meet [16]. India can be the reference as this country is the second biggest producer of clay bricks. Indian has promoted the road map for cleaner brick production and has been successful in reducing the particles matters (PM2.5) emission [29].

The researchers realize that there are weaknesses in this study that needs to be a concern. In this study, we do not collect information on family smoking habits and protein intake. Hence, these two variables could contribute to the length growth of children. Therefore, in the next study, researchers need to investigate maternal health and follow-up the length growth and children cognition at school age.

\section{Conclusion}

The presence of clay brick kilns in villages has affected the health of children. The real effect was in length attainment which is at the age of over 18-24 months, children in the areas of clay brick kilns were shorter $1.5-2.0 \mathrm{~cm}$. Median WHO standard can be used as the borderline to assess the growth attainment of children.

The prevalence of stunting was relatively high. These findings can be alarming for the Indonesian government in managing the establishment of clean clay brick kilns in rural and prevention of stunting at the village level.

\section{References}

1. Nasir M, Rehman FU, Kishwar S, Bashir S, Adil M. Air pollution and child health: The impact of brick kiln pollution on children's 
cognitive abilities and physical health in Pakistan. Environ Dev Sustain. 2021;23(9):13590-606. https://doi.org/10.1007/ s10668-021-01229-y

2. Kyu HH, Georgiades K, Boyle M. Maternal smoking, biofue smoke exposure and child height-for-age in seven developing countries. Int J Epidemiol. 2009;38(5):1342-50. https://doi. org/10.1093/ije/dyp253

PMid:19622677

3. Sebiany AM, Hafez AS, Salama KFA, Sabra AA. Association between air pollutants and anthropometric measurements of boys in primary schools in Dammam, Eastern Saudi Arabia. J Family Community Med. 2018;25(3):155-62. https://doi. org/10.4103/jfcm.JFCM_34_18 PMid:30220844

4. Bobak M, Richards M, Wadsworth M. Relation between children's height and outdoor air pollution from coal-burning sources in the British 1946 birth cohort. Int Arch Occup Environ Health. 2004;77(6):383-6. https://doi.org/10.1007/s00420-004-0522-5 PMid:15338223

5. Islam S, Rana MJ, Mohanty SK. Cooking, smoking, and stunting: Effects of household air pollution sources on childhood growth in India. Indoor Air. 2021;31(1):229-49. https://doi.org/10.1111/ ina. 12730

PMid:32779283

6. Balietti A, Datta S. The Impact of Indoor Solid Fuel Use on the Stunting of Indian Children. Amsterdam, Netherlands: Elsevier; 2017.

7. Bhagowalia P, Gupta P. Nutritional Status and Access to Clean Fuels: Evidence from South Asia; 2011.

8. Mishra V, Retherford RD. Does biofuel smoke contribute to anaemia and stunting in early childhood? Int J Epidemiol. 2007;36(1):117-29. https://doi.org/10.1093/ije/dyl234 PMid:17085456

9. Prasad R, Singh A, Garg R, Giridhar GB. Biomass fuel exposure and respiratory diseases in India. Biosci Trends. 2012;6(5):219-28. https://doi.org/10.5582/bst.2012.v6.5.219 PMid:23229114

10. Abraham M, Alramadhan S, Iniguez C, Duijts L, Jaddoe VW, den Dekker HT, et al. "A systematic review of maternal smoking during pregnancy and fetal measurements with meta-analysis. PLoS One. 2017;12(2):e0170946. https://doi.org/10.1371/ journal.pone. 0170946

PMid:28231292

11. Muraro AP, Gonçalves-Silva RM, Moreira NF, Ferreira MG, Nunes-Freitas AL, Abreu-Villaça Y, et al. Effect of tobacco smoke exposure during pregnancy and preschool age on growth from birth to adolescence: A cohort study. BMC Pediatr. 2014;14:99. https://doi.org/10.1186/1471-2431-14-99

PMid:24721026

12. Badan Pusat Statistik. Profil Penduduk Indonesia Hasil SUPAS2015. Available from: https://www.bps.go.id/ publication/2016 [Last accessed on 2021 Jul 25].

13. Isparwati R. Pekerjaan-Masyarakat-Desa; 2020. Available from: https://www.riniisparwati.com/pekerjaan-masyarakat-desa [Last accessed on 2021 Jul 25].

14. Dalkılıç N, Nabikoğlu A. Traditional manufacturing of clay brick used in the historical buildings of Diyarbakir (Turkey).
Front Archit Res. 2017;6(3):346-59. https://doi.org/10.1016/j. foar.2017.06.003

15. Badan Litbangkes Kementerian Kesehatan RI. Hasil Utama RISKESDAS 2018. Indonesian: Kemenkes RI; 2018. p. 20-1.

16. Kementerian Perencanaan Pembangunan Nasional. Siaran Pers Stunting Summit: Komitmen Bersama Turunkan Prevalensi Stunting di Indonesia; 2018.

17. Kemenkes RI. Hasil Utama Riskesdas 2018 Kesehatan. Indonesia: Kemenkes RI; 2018. p. 20-1.

18. de Onis M, WHO. WHO Child Growth Standards. Growth Velocity Based on Weight, Length and Head Circumference. Geneva: WHO Library Cat; 2009.

19. WHO. WHO child growth standards. Dev Med

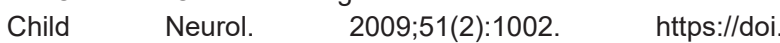
org/10.1111/j.1469-8749.2009.03503.x

20. Fenn B, Penny ME. Using the new World Health Organisation growth standards: Differences from 3 countries. J Pediatr Gastroenterol Nutr. 2008;46(3):316-21. https://doi.org/10.1097/ MPG.0b013e31815d6968

PMid:18376251

21. Ghaemmaghami P, Ayatollahi SM, Alinejad V, Sharafi Z. Growth curves and their associated weight and height factors in children from birth to 4 years old in West Azerbaijan Province, northwest Iran. Arch Pediatr. 2018;25(6):389-93. https://doi.org/10.1016/j. arcped.2018.06.010

PMid:30119913

22. Ayatollahi SM, Haem E, Sharafi Z. Growth velocity of infants from birth to 5 years born in Maku, Iran. Glob J Health Sci. 2015;8(2):56-63. https://doi.org/10.5539/gjhs.v8n2p56 PMid:26383193

23. Schwinger C, Fadnes LT, Van den Broeck J. Using growth velocity to predict child mortality. Am J Clin Nutr. 2016;103(3):801-7. https://doi.org/10.3945/ajcn.115.118679

PMid:26843152

24. Sinaga HT, Siagian A, Lubis Z, Aritonang E. Using bubble score chart as the main media in nutrition education to improve mothers knowledge and child weight gain in Deli Serdang distric, Indonesia. J Biol. 2015;3208(6):1-15.

25. Sinaga HT, Mahdiah M, Manalu M. Using modified growth chart in posyandu effectively improved child weight gain in Deli Serdang district, Indonesia. Pak J Nutr. 2015;14(9):547-52. https://doi.org/10.3923/pjn.2015.547.552

26. Nikolić M, Stanković A, Jović S, Kocić B, Bogdanović D. Effects of air pollution on growth in schoolchildren. Coll Antropol. 2014;38(2):493-7.

PMid:25144978

27. WHO, UNICEF \& Group. Levels and Trends in Child Malnuutrition. Geneva: WHO; 2018. p. 1-16.

28. Casale D, Desmond C. Recovery from stunting and cognitive outcomes in young children: Evidence from the South African birth to twenty cohort study. J Dev Orig Health Dis. 2016;7(2):163-71. https://doi.org/10.1017/S2040174415007175 PMid:26399543

29. Maithel S, Uma R, Bond T, Baum E, Thao V. Brick Kilns Performance Assessment a Roadmap for Cleaner Brick Production in India, Analysis; 2012. p. 164. 